\title{
Experiential Metafunction In Narrative Texts
}

\author{
Alemina \\ Universitas Sumatera Utara, Medan, North Sumatera \\ Nanang Panggabean \\ STBA-PIA, Medan, North Sumatera
}

\begin{abstract}
This study was aimed at describing the types of process and the reason of using those types in two narrative texts. It was conducted by using descriptive qualitative design. The data were collected by using documetary technique. There were 170 clauses in the story of Sleeping Beauty which contained material process $(120 / 70,5 \%)$,mental process $(9 / 5,3 \%)$, relational process $(17 / 10,5 \%)$, verbal process $(8 / 4,7 \%)$, behavioral process $(12 / 7,1 \%)$ and existential process $(4 / 2,3 \%)$. In the story of Zeus, there were 112 clauses which contained material process $(81 / 72 \%)$, mental process $(3 / 2,7 \%)$, relational process $(23 / 20,9 \%)$, verbal process $(2 / 1,8 \%)$,behavioral process $(2 / 1,8 \%)$ and existential process $(1 / 0,9 \%)$. From the data, it was concluded that all the types of processes were found in both strories. The reason of using those types because there was some descriptions of the events and were dominated by the act of doing performed by the participants.
\end{abstract}

Keywords: Experiential, Metafunction, Narrative

\section{Introduction}

According to Halliday \& Matthiessen (2004:10), grammar as system, enabling us to show the grammar as a meaning-making resource and to describe grammatical categories by reference to what they mean. The theory that rules this meaning-making in discourse is the theory of Systemic Functional Linguistics (SFL). SFL focuses on the language in use which means that the language is a resource for meaning-making based on the context where the language takes place. It is divided into three categories, they are: ideational, interpersonal, and textual functions. The social context of a discourse is realized through the meta-function of language. Sinar (2002:12) states that meta-function of language is the concept that enables us to understand the relation between things outside the language and the relation that has shaped the form of grammar.

In this study, the focus is on experiential function. It is coded when people represent their experience of the world. Halliday (2004:110) states that experiential 
function is realized through the elements of (1) the process itself (realized by verbal group); (2) participants in the process (realized by nominal group); (3) circumstances associated with the process (realized by adverbial group or prepositional phrase). Unlike circumstance, in experiential function, participant and process are obligatory because it is impossible to share his feelings and thoughts without knowing who has the experience and what kind of activity he or she has to be categorized as experience.

In educational context, the written text or material is an important learning resource. Specifically, written material of texts can be found in text genres such as recount, report, exposition, discussion, narrative and descriptive texts (Pardiono, 2007:18). In order to understand the genre well, the experiential function of the text should be well recognized as it characterizes the genre itself. Rahmadia (2011) on her study about the transitivity process of inauguration speeches of two prime ministers of Australia John Howard and Julia Gillard found that relational process was the dominant type of process, followed by behavioral and existential process. She stated her finding was due to the excessive use of describing things to the audiences. Besides, the study was set in an oral mode of communication and with the goal of introducing putting someone into an important position.

Different mode of communication may have different variety of process especially when it is linked to the text-genre. This research was focused on the experiential function applied in two narrative texts. Narrative texts are chosen because this kind of text is the first lesson of genre for Indonesian students.

Based on the description above, this research is intended to find the forms and the reasons of using experiential function in two narrative texts under the title of Experiential Metafunction in Narrative Texts.

\section{Method}

This research was conducted with descriptive qualitative design. Qualitative research focuses on understanding social phenomena in natural settings. It is the method when straight descriptions of phenomena are desired (Sandelowski, 2000). Thus, descriptive qualitative design is used to describe an experience or event in natural setting by displaying words on its interpretation rather than numbers.

This research described about the experiential meta-function used in the fairy tale and myth story entitled of Sleeping Beauty from Brothers Grimm (2013) as fairy tale story 
and The Story of Zeus as myth story from Berens, E.M (2009), and explained about the reason of processes, participants and circumstances in the narrative texts.

To collect the data, this study used documentary technique. Arikunto (2007) states that documentary technique means collecting some samples from the communication or narrative text. In collecting the data, some steps were followed: (a) Reading the whole stories downloaded from internet; (b) analyzing the texts in which the sentences used experiential function; and (c) categorizing the sentences according to the types of experiential function.

The data was analyzed by using following Miles \& Huberman (2014:31) through three steps: data condensation, data display, and conclusion drawing.

\section{Result}

Theoretically, experiential function consists of the process, participants, and circumstances. The process is subdivided into material, mental, relational, verbal, behavioral, and existential.

Practically, all types of processes were used as it could be seen in these following data.

\section{Material process}

According to Halliday in Saragih (2014:47) Material process are processes of doing or happening. One who performs action as actor and the object of the action is the goal. Based on this concept, the data analysis shows that this type of process in this text as shown in data 1 .

Data 1

Once upon a time there lived a king and queen,

\begin{tabular}{|c|c|c|c|}
\hline $\begin{array}{l}\text { Once upon a } \\
\text { time }\end{array}$ & There & lived & a king and queen \\
\hline Circ: Time & Part II: goal & $\begin{array}{l}\text { Proc: } \\
\text { Material }\end{array}$ & Participants: Actor \\
\hline
\end{tabular}

From the data above, the word "lived" was material process because the word expressed physical action. It also had two participants (actor) "a king and a queen" and goal represented in the use of "there".

\section{Mental process}


Halliday in Saragih (2014: 47) states that mental process expresses mental phenomena such as perception (see, look), reaction (like, please), and cognition (know, believe, convince). Mental process involves two participants, they are senser and phenomenon. Based on this concept, the data analysis showed that this type of process was found in this text as shown in data 2 below.

Data 2

In the courtyard the prince saw horses

\begin{tabular}{|l|l|l|l|}
\hline In the courtyard & the prince & saw & horses \\
\hline Circ: place & Senser & $\begin{array}{l}\text { Process:mental- } \\
\text { perception }\end{array}$ & phenomenon \\
\hline
\end{tabular}

From data 2 above, the word "saw" was a mental process since it expressed perception and it also had a participant, such as "the prince" as a senser, and "horses" as the phenomenon.

\section{Relational process}

Relational process is a process of being. It is divided into attributive, identifying, and possessive. Attributive is constituted by carrier + attribute; identifying consists of token/identifier + value/identified; and possessive includes possessor + possessed. Based on this concept, the data below showed how relational process existed in the narrative text.

Data 3

But it was all in vain.

\begin{tabular}{|l|l|l|}
\hline It & Was & all in vain \\
\hline token & Process: relational-identifying) & Value \\
\hline
\end{tabular}

From data 3 above, the word "was" was a relational process specified in identifying type since the word expressed a process of identifying. Besides, it also had the identifier "it" and the value "all in vain" as the identified part.

\section{Verbal process}

Verbal process are processes of saying (Halliday, 1994:14). This process has sayer, receiver/target, and verbiage as its participants. Based on this theory, the data analysis shows that this type of plrocess is found in the text as shown in data 4.

Data 4

told the princess aloud 


\begin{tabular}{|l|l|l|}
\hline Told & the princess & Aloud \\
\hline Process: verbal & Sayer & Circ: manner \\
\hline
\end{tabular}

From the data above, the word"told" is a verbal process since the word express a process of saying, and it also has participant namely "the princess"(sayer).

\section{Behavioral process}

According to Saragih (2014:47), behavioral processes refer to physiological and psychological behavior such as breathing, coughing, smiling, lauging, crying, staring, dreaming, etc. In behavioral process, there was only one participant called as behaver, which is often a human. The data that represented behavioral process could be seen below:

Data 5

as if she had just fallen asleep.

\begin{tabular}{|l|l|l|}
\hline As if & She & Had just fallen asleep \\
\hline Contingency: condition & Behaver & Process: behavioral \\
\hline
\end{tabular}

From the data above, the word "had just fallen asleep" was a behavioral process because the word implied physiological and psychological behavior, and the behaver was identified through the use of "she" and the contingency circumstances "as if".

\section{Existential process}

Existential process represents that something exists or happens. Existential process could be seen in the data below.

Data 6

There an old woman so old and deaf.

\begin{tabular}{|l|l|l|}
\hline There & an old woman & so old and deaf \\
\hline Process:existential & existent & Cir:condition \\
\hline
\end{tabular}

From data 6 above, "there" is an existential process since the word represents somenthing exist or happen, and it also has one participant "an old woman" (existent) and so old and deaf as the circumstances.

There were six types of process found in narrative text of "Sleeping Beauty" and "Story of Zeus". The findings are summarized below:

Table 3.1. Types of Process Used in Sleeping Beauty and Story of Zeus

\begin{tabular}{|l|l|l|l|}
\hline No. & Types of process & Sleeping Beauty story & Story of Zeus \\
\hline
\end{tabular}




\begin{tabular}{|l|c|c|c|l|c|}
\hline & & Frequency & Percentage & Frequency & Percentage \\
\hline 1 & Material & 120 & $70.5 \%$ & 81 & $72 \%$ \\
\hline 2 & Mental & 9 & $5.3 \%$ & 3 & $2.7 \%$ \\
\hline 3 & Relational & 17 & $10.05 \%$ & 23 & $20.9 \%$ \\
\hline 4 & Behavioral & 8 & $4.7 \%$ & 2 & $1.8 \%$ \\
\hline 5 & Verbal & 12 & $7.1 \%$ & 2 & $1.8 \%$ \\
\hline 6 & Existential & 4 & $2.3 \%$ & 1 & $0.9 \%$ \\
\hline & Total & 170 & $100 \%$ & 112 & $100 \%$ \\
\hline
\end{tabular}

The table above represented the amount of each type of process used in both narrative texts. It also implied that the reason of having those types of process was because the texts consisted of the description of the events followed by other process.

\section{Discussion}

Based on the finding above, it was concluded that all types of process in transitivity system were found in both narrative texts. There were six types of processes in transitivity system namely: material process, mental process, relational process, verbal process, behavioral process, and existential process. All types of process could be found in both narrative texts because the essence of narrative text was to show the readers about the sequence of events along with the actions done by the participants. Similar with Oktoma (2017) who studied about process types in students' narrative text. The researcher found that there were four main processes existed in narrative text entitled of Rabbit and Twenty Crocodiles such as material (62.53\%), mental (11.05\%), verbal (11.32\%), and relational process $(15.1 \%)$. The similarity between Oktoma's and this study was about the dominant one that was material process and followed by relational process. Thus, it could be said that narrative text commonly used various process throughout the paragraphs. However, the limitation of this study should be acknowledged as it did not mention the level of complexity of narrative text that the researcher intended to study. The narrative text addressed for young children, teenagers, and adults may reveal more or less types of process. So, for the further researchers it was suggested to conduct a study in relation to this matter. 


\section{References}

Halliday, M. A. K., \& Matthiessen, C. M. I. (2004). An Introduction to Functional Grammar. London: Routledge.

Halliday, M. A. K. (1994). An Introduction to Functional Grammar. London: Edward Arnold

Miles, H et.al (2014). Qualitative Data Analysis. London: SAGE Publications, Inc.

Oktoma, E. (2017). Process Types in Students' Narrative Text. Indonesian EFL Journal. 3(1), 79-88

Pardiono. (2007). Pasti Bisa!! Teaching Genre- Based Writing: Metode Mengajar Writing Berbasis Genre Secara Efektif. Yogyakarta: Andi Press.

Rahmadiana. (2011). An Analysis of Transitivity Process of Inauguration Speeches of Two Prime Ministers of Australia : John Howard and Julia Gillard. Unpublished Thesis.

Sandelowski, M. (2000). Whatever Happened to Qualitative Description? Focus on Research Methods. 334-340

Saragih, A. (2013). Discourse Analysis: A Study on Discourse Based on Systemic Functional Linguistic Theory.

Sinar, T.S. (2003). Teori \& Analisis Wacana (Pendekatan Sistemik Fungsional). Medan: Pustaka Bangsa Press. 